\title{
Water productivity of different land uses in watersheds assessed from satellite imagery Landsat 5 Thematic Mapper
}

\author{
Renato A.M. Franco ${ }^{\mathrm{a}}$, Fernando B.T. Hernandez ${ }^{*}$, Antonio H.C. Teixeira ${ }^{\mathrm{c}}$ \\ ${ }^{a, b}$ UNESP - Universidade Estadual Paulista, Ilha Solteira, São Paulo, Brazil; ${ }^{c}$ Embrapa \\ Monitoramento por Satélite, Campinas, São Paulo, Brazil
}

\begin{abstract}
Water productivity (WP) of various classes of soil usage from watersheds was estimated using the SAFER - Simple Algorithm For Evapotranspiration Retrieving - algorithm and the Monteith equation to estimate the parameters of biomass production (BIO). Monteith's equation is used to quantify the absorbed photosynthetically active radiation (APAR) and Actual Evapotranspiration (ET) was estimated with the SAFER algorithm. The objective of the research is to analyze the spatial-temporal water productivity in watersheds with different uses and soil occupation during the period from 1996 to 2010, in conditions of drought and using the Monteith model to estimate the production of BIO and using the SAFER model for ET. Results indicated an increase of 153.2\% in ET value during the period 1997-2010, showing that the irrigated areas were responsible for this increase in ET values. In September 2000, image of day of year (DOY) 210 showed high values of BIO, with averages of $80.67 \mathrm{~kg} \mathrm{ha}^{-1} \mathrm{~d}^{-1}$. In the year 2010 (DOY:177), the mean value of BIO was $62.90 \mathrm{~kg} \mathrm{ha}^{-1} \mathrm{~d}^{-1}$, with an irrigated area with a maximum value of $227.5 \mathrm{~kg} \mathrm{ha}^{-1} \mathrm{~d}^{-1}$. The highest incremental values of $\mathrm{BIO}$ is verified from the start of irrigated areas equal to the value of ET, because there is a relationship between BIO and ET. The maximum water productivity (WP) value occurred in June $/ 2001$, with $3,08 \mathrm{~kg} \mathrm{~m}^{-3}$, the second highest value was in 2010 (DOY:177), with a value of $2,97 \mathrm{~kg} \mathrm{~m}^{-3}$. Irrigated agriculture show the highest WP value, with maximum value of $6.7 \mathrm{~kg} \mathrm{~m}^{-3}$. The lowest WP was obtained for DOY 267, because of the dry season with condition of low soil moisture.
\end{abstract}

Keywords: evapotranspiration, biomass production, SAFER (Simple Algorithm For Evapotranspiration Retrieving), land use change, water productivity, Landsat $5 \mathrm{TM}$

\section{INTRODUCTION}

Population growth and climate changes can affect the availability of food and water in the coming decades ${ }^{1}$. Anthropogenic activities such as urbanization and agriculture can modify the land surface, by changing the pattern of use and land cover and interfering in various environmental factors.

Irrigated agriculture in Brazil uses surface water, and its primary feedstock to meet the water demand of plants and therefore should adopt research on efficient water use in crop production, with the development and appli-cation of tools for analysis and planning of water use.

The northeastern region has the highest rate of evapotranspiration of São Paulo State ${ }^{2}$ and eight months of water deficiency in the soil (April-November) may occur ${ }^{3}$. For this reason, the use of an irrigation system is important to replenish the water requirement and ensure maximum crop yield. The weather is a major factor affecting agricultural production and irrigated agriculture is dependent of agrometeorological information to run an efficient management and provide the required amount of water to replenish the water deficit of the agricultural crops.

Weather is a factor that affects agricultural production and irrigation is dependent on agrometeorological data to run efficient management and provide the required amount of water to replenish the water deficit of agricultural crops.

*fbthtang@agr.feis.unesp.br

Remote Sensing for Agriculture, Ecosystems, and Hydrology XVI, edited

by Christopher M. U. Neale, Antonino Maltese, Proc. of SPIE Vol. 9239, 92392E

(C) 2014 SPIE - CCC code: 0277-786X/14/\$18 - doi: 10.1117/12.2067459

Proc. of SPIE Vol. 9239 92392E-1 
The parameters of water productivity on large scale is an important tool to support the planning of agricultural policies and decision making about the use of natural resources ${ }^{4}$. The water applied to plants provides increase of biomass production (BIO) and evapotranspiration (ET) rate in a large scale ${ }^{5,6}$.

$\mathrm{BIO}$ is related to a photosynthetic active radiation (PAR) that is part of the short wave solar radiation (0.3 to $3.0 \mu \mathrm{m})$ absorbed by chlorophyll in photosynthesis and the energy of the PAR uses only $40 \%$ to $50 \%$ of the total solar radiation. $\mathrm{BIO}$ is a measure to assess the ability to produce plant dry matter by using a photosynthetic process that converts solar energy into biomass. The quantification of BIO in large scale allows comparisons between different types of crops by promoting spatial and temporal information, and its estimate is based on incoming shortwave solar radiation (RS $\downarrow$ ).

The model developed by Monteith ${ }^{7}$, associated with the parameters obtained by satellite is acceptable and was applied in the watershed of the São Francisco River with satisfactory results ${ }^{4,5,6}$.

Water productivity (WP) estimates the value obtained from each unit volume of water used in the production of a given product $^{8}$. These authors emphasize that considering the vegetation, WP can be the BIO for the water consumed by the vegetated surface, including the water that originates from precipitation, irrigation, runoff and soil moisture variations.

For the determination of WP, evapotranspiration (ET) to be quantified. The SAFER (Simple Algorithm for Retrieving Evapotranspiration) allows to estimate ET using the Penman-Monteith equation in conjunction with biophysical parameter data generated through the use of remote sensing ${ }^{9,10}$.

The objective of the research is to determine the spatial and temporal water productivity in watersheds with different types of use and occupation of land in their driest conditions, during the period 1997-2010, using Landsat TM-5 together with the Monteith model to estimate the parameters of BIO and SAFER for determination of ET on a large scale.

\section{MATERIAL AND METHODS}

\subsection{The study area and data collection}

The research was carried out in the Tietê river basin which is located in the northeastern region of São Paulo State (Figure 1).

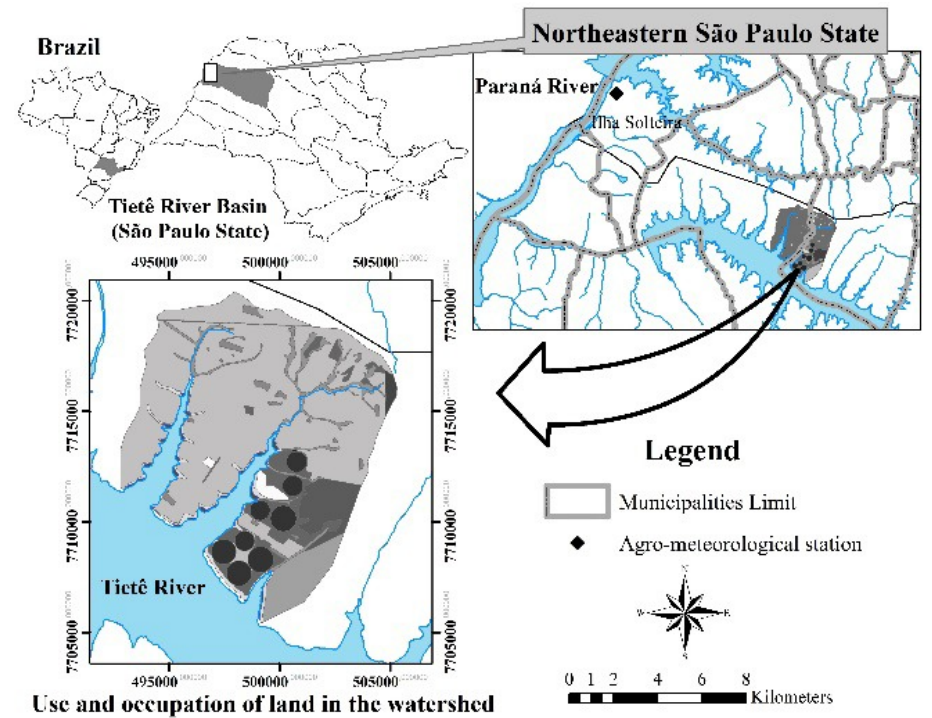

Figure 1. Location of the research area.

The three watersheds summed up a total of an area of $103.10 \mathrm{~km} 2$ and have different types of use and occupation of land occupied mostly by pasture and irrigated agriculture that began in 1997, due to favorable growing conditions, with water availability, relief and soil fertility. Other types of land use are sugarcane and natural vegetation, the last with lowest area.

One automatic weather station was used together with 14 Landsat images for the periods of water deficit from 1997 to 2010. 
The use of agrometeorological data from an automatic weather station located in the municipality of Ilha Solteira and operated by UNESP ${ }^{17}$. The global solar radiation (RS $\downarrow$ ), air temperature $\left(\mathrm{T}_{\mathrm{a}}\right)$ and reference evapotranspiration $\left(\mathrm{ET}_{0}\right)$ data were inserted in with remote sensing data for modeling of BIO and ET in large scale.

The Landsat TM-5 images used in the research correspond to the period of water deficit as shown on the water balance of the studied region. The images were identified in Julian years and days (JD), as shown below: 1996/218; 1997/237; 1998/208; 1999/211; 2000/261; 2001/157; 2001/296; 2003/286; 2005/227; 2007/249; 2008/267; 2009/238 and 2010/177. The image of the year /JD - 2004/80 does not correspond to the period water deficit, it was selected for reasons of clouds in other images of the period.

\subsection{Simple Algorithm for Retrieving Evapotranspiration (SAFER)}

The remote sensing parameters involved in NDVI (Normalized Diference Vegetation Index), surface albedo $\left(\alpha_{0}\right)$, surface temperature $\left(\mathrm{T}_{\mathrm{a}}\right)$ were determined and added in the equation below ${ }^{9,10,11}$ :

$$
\frac{E T}{E T_{0}}=\exp \left[a+b\left(\frac{T_{0}}{\alpha_{0} N D V I}\right)\right]
$$

where a and $\mathrm{b}$ are regression coefficients 9 . For this study adopted value 1.0 for the "a" and -0.008 for the "b" coefficients of the Equation (Eq.) $1^{11}$. The evapotranspiration reference $\left(\mathrm{ET}_{0}\right)$ was obtained in an automatic station and added in Eq. 1 .

\subsection{Net Radiation $\left(\mathbf{R}_{\mathbf{n}}\right)$}

The daily (24-hour) values of net radiation $\left(\mathrm{R}_{\mathrm{n}}\right)$ were determined according to Eq. $2^{2,5,6,9,12}$ :

$$
\mathrm{R}_{\mathrm{n}}=\left(1-\alpha_{0}\right) \mathrm{RS} \downarrow-\mathrm{a} \tau_{\mathrm{sw}}
$$

where RS $\downarrow$ is the incoming global solar radiation obtained in the agro-meteorological station; a is the regression coefficient of the relationship between net long wave radiation and atmospheric transmissivity $\left(\tau_{\mathrm{sw}}\right)$ at the daily scale, according to the following Eq. 3:

$$
a=b T_{a}-c
$$

where $b$ and $c$ - are regression coefficients and show the following values, 6.99 and 39.93, respectively ${ }^{5} \mathrm{~T}_{\mathrm{a}}$ the air temperature is obtained in the agro-meteorological station (Figura 1).

\subsection{Photosynthetically Active Radiation (PAR)}

It's the part of the short wave solar radiation $(0.3$ to $3.0 \mu \mathrm{m})$ that supports photosynthesis in green plants. The daily values of RS $\downarrow$ for each Julian day were used to estimate the values of Photosynthetically Active Radiation (PAR) for the same time scale (24 hours):

$$
P A R=a R S \downarrow\left(\mathrm{W} \mathrm{m}^{-2}\right)
$$

were $\mathrm{a}=0.44$ is the constant of the regression equation found under the Brazilian semiarid conditions that reflects the portion of RS $\downarrow$ that can be used by leaf chlorophyll for photosynthesis ${ }^{4,5,6}$.

It was estimated from the Eq.5 by obtaining the Absorbed Photosynthetically Active Radiation (APAR):

$$
A P A R=f P A R\left(\mathrm{~W} \mathrm{~m}^{-2}\right)
$$

were: $\mathrm{f}$ - was determined from Eq.6.

$$
f=a N D V I+b\left(\mathrm{~W} \mathrm{~m}^{-2}\right)
$$

The factor $\mathrm{f}$ was estimated from the NDVI values. Where the values of $\mathrm{a}$ and $\mathrm{b}$ are $1.257,-0.161$, respectively $\mathrm{y}^{6,14}$.

\subsection{Production Biomass (BIO)}

$\mathrm{BIO}$ was then obtained as: 


$$
B I O=\varepsilon_{\max } \times E_{f} \times A P A R \times 0.864
$$

where $\mathrm{Ef}$ (evaporative fraction)is the ratio of the latent heat flux $(\lambda \mathrm{E})$ to $\mathrm{R}_{\mathrm{n}}$, being $\lambda \mathrm{E}$ acquired by transforming ET into energy units; $\varepsilon_{\max }$ is the maximum light use efficiency, which was considered $2.5 \mathrm{~g} \mathrm{MJ}^{-1}$ for the majority of $\mathrm{C}_{4}$ species in the studied area; and 0.864 is a unit conversion factor ${ }^{6}$.

\subsection{Water productivity (WP)}

For water productivity (WP) analysis, involving the watershed, the following equation was used ${ }^{4,16}$ :

$$
W P=\frac{B I O}{E T}
$$

where $\mathrm{BIO}$ was obtained from the Eq.7 and ET was acquired in Eq.1.

\section{RESULTS AND DISCUSSION}

Figure 2 presents spatial variation of the NDVI values and the average for each JD/year of the assessed watersheds. The average study period was 0.40 , the lowest mean value was 0.31 and occured in 2008 . The highest value occurred in 2001 , with an average value of 0.53 .

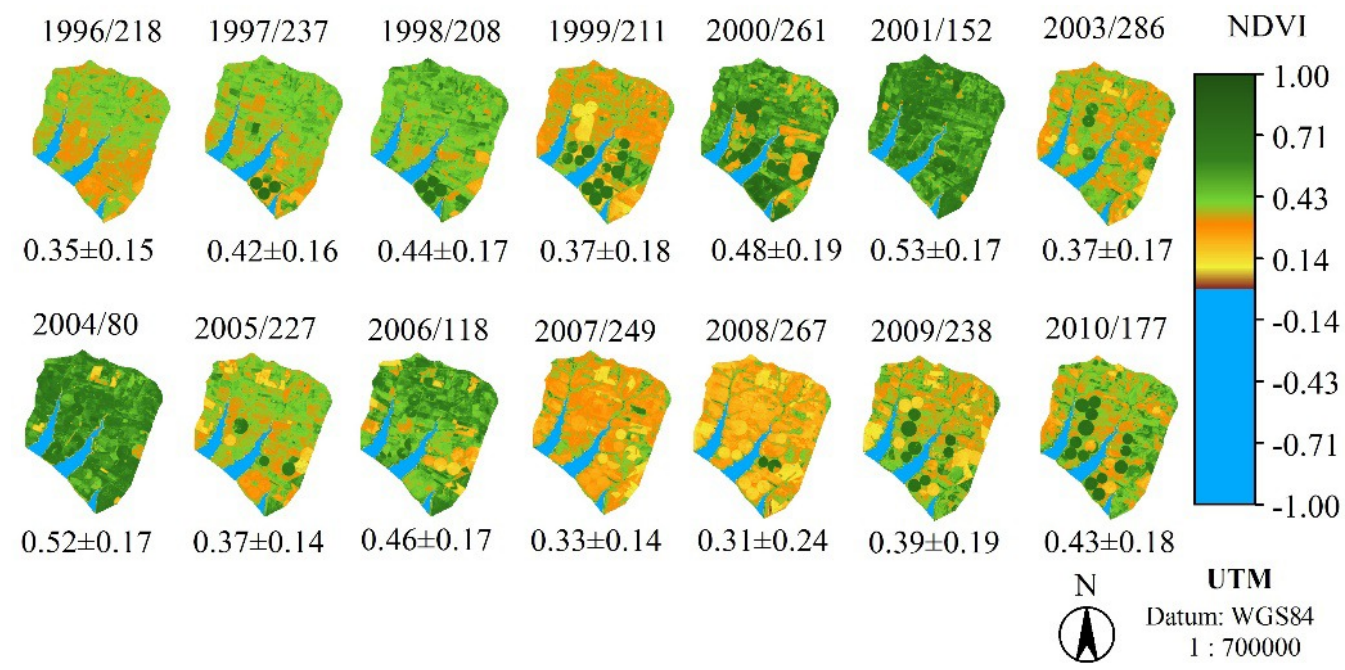

Figure 2. Spatial distribution of the value of the NDVI for the watersheds during the years from 1996 to 2010 , for every day of the year (DOY), average NDVI and SD value.

In irrigated areas, high NDVI values were found, with 0.69 and an average value of 0.44 for the study period. Other class of land cover which presented high NDVI values were a natural vegetation, cittrus, pasture, with values of $0.46,0.45$ and 0.43 , respectively.

Figure 3 shows the spatial distributions of daily values of BIO from 1996 to 2010 for every JD / year, average and standard deviation (SD). Analysing only irrigated crops, in 1998 (DJ: 208) the are irrigated by center pivots presented in average $116.4 \mathrm{~kg} \mathrm{ha}^{-1} \mathrm{~d}^{-1}(\mathrm{SD}: \pm 21.4)$ and in 1999 it was $76.2 \mathrm{~kg} \mathrm{ha}^{-1} \mathrm{~d}^{-1}$ (SD: \pm 44.7$)$. In September 2000 (JD: 261), the maximum value was $277.4 \mathrm{~kg} \mathrm{ha}^{-1} \mathrm{~d}^{-1}$ and an average of 142.8 (SD: \pm 64.2 ). The second highest value happened in 2004 (JD: 80, March), with maximum value of $188.8 \mathrm{~kg} \mathrm{ha}^{-1} \mathrm{~d}^{-1}$ and an average of $74.1 \mathrm{~kg} \mathrm{ha}^{-1} \mathrm{~d}^{-1}$ (SD: 45.4). The third greatest value occurred in June (2010/DJ: 177), with a maximum value of $227.5 \mathrm{~kg} \mathrm{ha}^{-1} \mathrm{~d}^{-1}$ and an average of $146.4 \mathrm{~kg} \mathrm{ha}^{-1} \mathrm{~d}^{-1}$ (SD: \pm 55.3). One the other hand, analyzing only the watersheds with different land use there is an increase in the standard deviation values, due to the start of the irrigated crop has happened since 1997 and the largest SD ocorred in 1999.

In the semi-arid region of Brazil ${ }^{4}$, lower values for BIO have been found between the months of July and September, and high values occurred in the rainy season which span from the period of February to April. In the northeastern São Paulo State, the image of March (2004/80) showed high value of BIO due to the rainy season in the region. In the dry season 
there is a reduction in the value of BIO in watershed, the values of BIO are high in irrigated areas due to the daily irrigation center pivots.

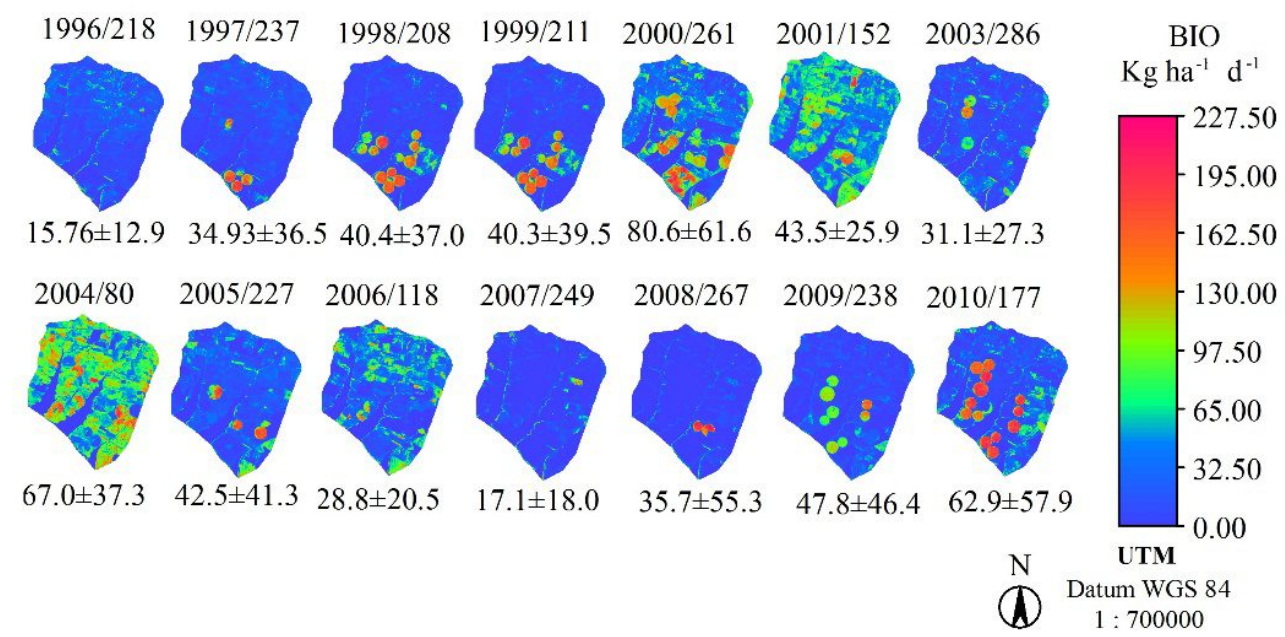

Figure 3. Spatial distribution of the value of BIO for the water-sheds during the years from 1996 to 2010 , for every day of the year (DOY), average BIO and SD value.

In the year 2010, the mean value of BIO in the watershed was 62.9 (SD: \pm 57.9 ). The differents types of use, pasture, sugarcane and natural vegetation showed the following average values: $56.3 \mathrm{~kg} \mathrm{ha}^{-1} \mathrm{~d}^{-1}$ (SD: 49.1); $46.9 \mathrm{~kg} \mathrm{ha}^{-1} \mathrm{~d}^{-1}$ (SD: \pm 30.3 ) and $40.5 \mathrm{~kg} \mathrm{ha}^{-1} \mathrm{~d}^{-1}$ (SD: \pm 26.8$)$, respectively.

Figure 4 shows the spatial distribution of the ET mean values for the period 1996-2010. The highest mean values of ET occurred in 2000 (SD: \pm 1.26 ), because the area irrigated by center pivot that averaged $2.2 \mathrm{~mm}^{-1} \mathrm{~d}^{-1}$ (SD: \pm 1.4 ). Mean values of ET showed an increment of $153.2 \%$ during the period 1997-2010, with the irrigated areas this increases in ET the values of watersheds.

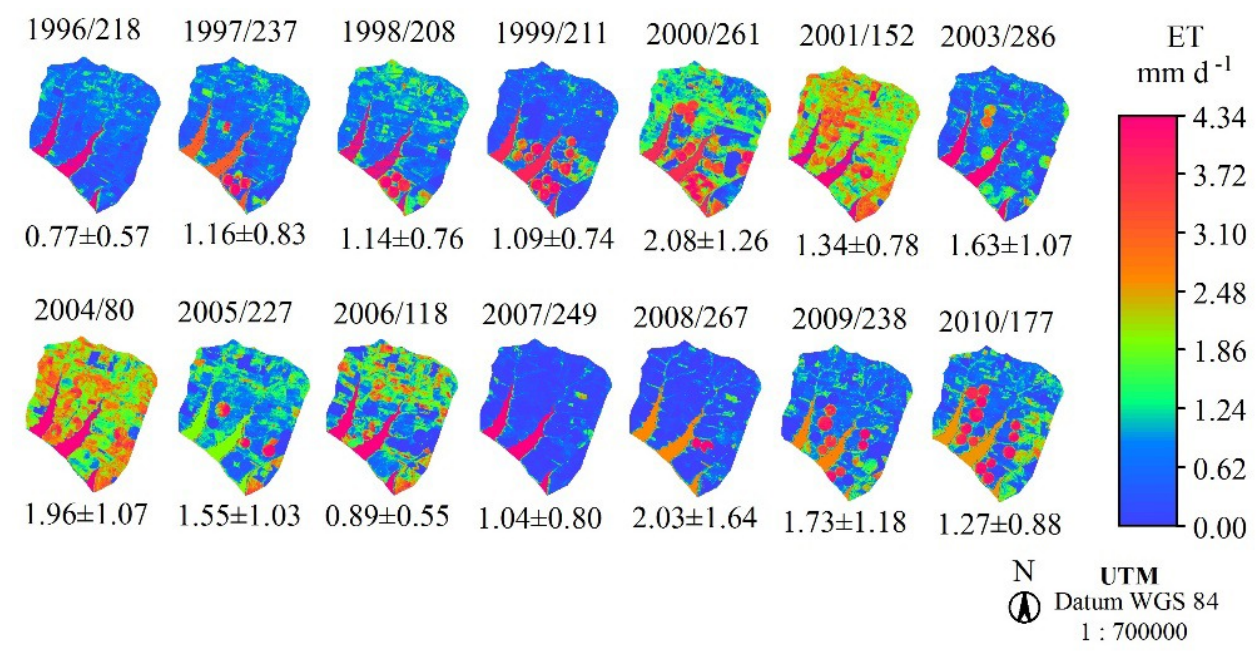

Figure 4. Spatial distribution of the value of evapotranspiration (ET) for the watersheds during the years of 1996 to 2010 , for every day of the year (DOY), average ET and SD value.

The maximum WP value occurred in June/2001 (DOY:152), with 3,08 $\mathrm{kg} \mathrm{m}^{-3}$ (SD: \pm 1.22 ), the second highest value was in 2010 (June/DOY:177), with a value of $2,97 \mathrm{~kg} \mathrm{~m}^{-3}$ (SD: \pm 1.52 ) (Figure 5). Irrigated agriculture show the highest WP value in 2010, with maximum value of $6.7 \mathrm{~kg} \mathrm{~m}^{-3}$ and mean value of $3.1 \mathrm{~kg} \mathrm{~m}^{-3}$ (SD: \pm 2.0 ).

The lowest WP was obtained by images of DOY 249 (September, 2007) and 267 (September, 2008), because of the dry season with low soil moisture conditions, with 90 and 120 days without rain above $10 \mathrm{~mm}$, respectively ${ }^{15}$. 
Assessing the WP for different types of land use, verified mean value of $2.9 \mathrm{Kg} \mathrm{m}^{-3}$ for the sugarcane not irrigated in 2010 (June), at the same date occurred a mean value of $2.3 \mathrm{Kg} \mathrm{m}^{-3}$ for natural vegetation. In 2001 the average value for natural vegetation was $3.4 \mathrm{Kg} \mathrm{m}^{-3}$ and sugarcane reached a maximum value of $5.0 \mathrm{Kg} \mathrm{m}^{-3}$, and mean $3.0 \mathrm{Kg} \mathrm{m}^{-3}$.

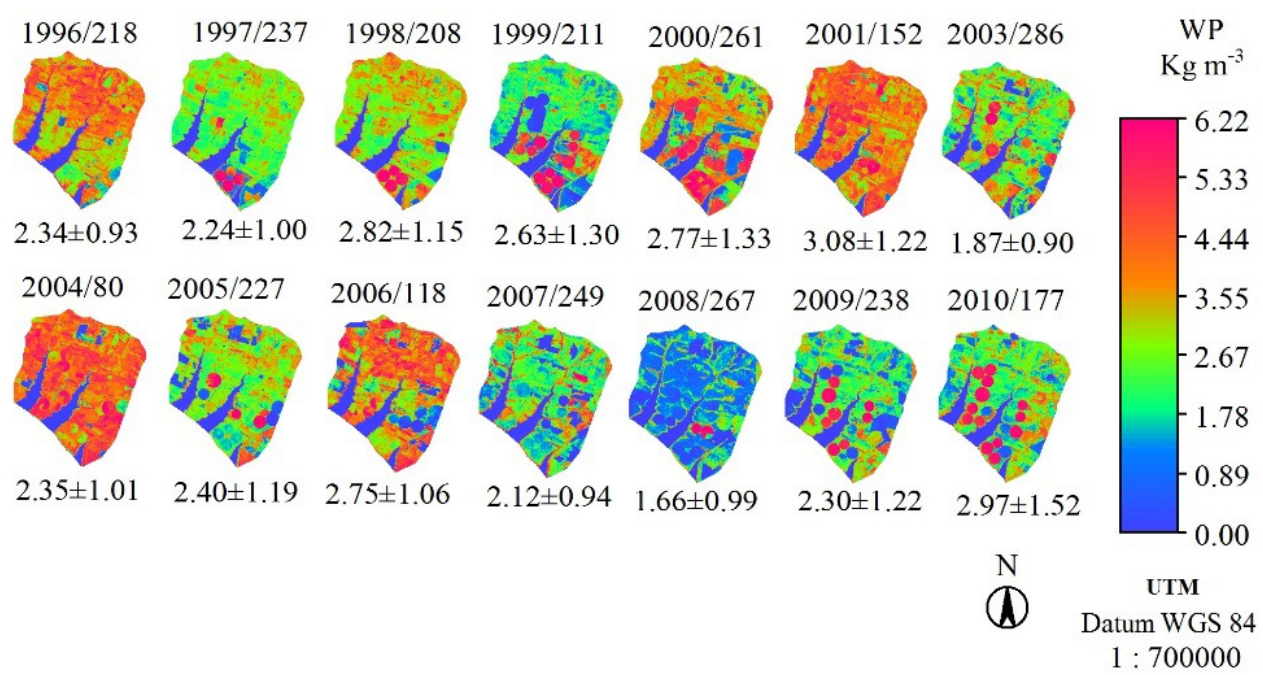

Figure 5. Spatial distribution of the value of WP for the watersheds during the years of 1996 to 2010, for every day of the year (DOY), means WP and SD value.

\section{CONCLUSIONS}

Combining remote sensing parameters from Landsat-TM satellite images and weather data from agro-meteorological stations allowed the water productivity assessment in watersheds along the years of 1996 to 2010 . The mean values of ET showed an increase of $153.2 \%$ during the period 1997-2010, with the irrigated areas this increase in ET values in watersheds.

SAFER model was efficient for the study and for identification of the termo-hydrological conditions of the imagens evaluated in the dry season.

WP values were higher in the irrigated, mainly in the crop production and reduction during the fallow period, represent by pixel redish.

\section{ACKNOWLEDGEMENTS}

FAPESP is acknowledged for the financial support on the Water Productivity Project (Process 2.009/52.467-4).

\section{REFERENCES}

[1] Wiltshire, A.J.; Kay, G.; Gornall, J.L.; Betts, A.R. The Impact of Climate, $\mathrm{CO}_{2}$ and Population on Regional Food and Water Resources in the 2050s. Sustainability (5), 2129-2151 (2013).

[2] Hernandez, F.B.T.; Souza, S.A.V.; Zocoler, J.L.; Frizzone, J.A. Simulação e efeito de veranicos em culturas desenvolvidas na região de Palmeira d'Oeste, Estado de São Paulo. Engenharia Agrícola (23), 21-30 (2003).

[3] Santos, G.O.; Hernandez, F.B.T.; Rosseti, J.C. Balanço hídrico como ferramenta ao planejamento ag-ropecuário para a região de Marinópolis, noroeste do Es-tado de São Paulo. Revista Brasileira de Agricultura Irrigada, 4(3), 142-149 (2010). $<$ http://www.agr.feis.unesp.br/pdf/rbai_v4_n3 p142_149 bh.pdf $>$ (19 october 2013).

[4] Teixeira, A.H.C.; Scherer-Warren, M.; Hernandez, F.B.T.; Andrade, R.; Leivas, J.F. Large-Scale Water Productivity Assessments with MODIS Images in a Changing Semi-Arid Environment: A Brazilian Case Study. Remote Sens (5), 5783-5804 (2013). 
[5] Teixeira, A.H.C.; Bastiaanssen, W.G.M; Ahmad, M.D; Bos, M. G. Reviewing SEBAL input parameters for assessing evapotranspiration and water productivity for the Low-Middle São Francisco River basin, Brazil Part A: Calibration and validation. Agricultural and Forest Meteorology (149), 462-476 (2009a).

[6] Teixeira, A.H.C.; Bastiaanssen, W.G.M.; Ahmad, M.D.; Bos, M. G. Reviewing SEBAL input parameters for assessing evapotranspiration and water productivity for the Low-Middle São Francisco River basin, Brazil Part B: Application to the large scale. Agricultural and Forest Meteorology (149), 477-490 (2009b).

[7] Monteith, J.L. Solar radiation and productivity in tropical ecosystems. Journal of Applied Ecology (9), 747-766 (1972).

[8] Molden, D.; Bin, D.; Loeve, R.; Barker, R.; Tuong, T. P. Agricultural water productivity and savings: policy lessons from two diverse sites in China. Water Policy, (9), 29-44 (2007).

[9] Teixeira, A.H.C. Determining regional actual evapotranspiration of irrigated and natural vegetation in the São Francisco river basin (Brazil) using remote sensing an Penman-Monteith equation, Rem. Sens. (2), 1287-1319 (2010).

[10] Teixeira, A.H.C.; Hernandez, F.B.T.; Lopes. H.L. Application of Landsat images for quantifying the energy balance under conditions of land use changes in the semi-arid region of Brazil. In: SPIE Remote Sensing Symposium, Edimburgo. Proc. of SPIE, 8531, 85310P-1-85310P-2 (2012).

[11] Teixeira, A.H.C.; Hernandez, F.B.T.; Lopes, H.L.; Sherer-Warren, M.; Bassoi, L.H. A comparative study of techniques for modelling the spatiotemporal distribution of heat and moisture fluxes in different agro-ecosystems in Brazil In: Remote Sensing of Energy Fluxes and Soil Moisture Content, George P. Petropoulos (editor). CRC Press, 165187 (2014).

[12] Teixeira, A.H.C.; Bastiaanssen, W.G.M.; Moura, M.S.B.; Soares, J.M.; Ahmad, M.D.; Bos, M.G. Energy and water balance measurements for water productivity analysis in irrigated mango trees, Northeast Brazil, Agr. Forest. Meteorol. (148), 1524-1537 (2008a).

[13] Teixeira, A.H.C; Bastiaanssen, W.G.M.; Ahmad, M.D.; Moura, M.S.B.; Bos, M.G. Analysis of energy fluxes and vegetation-atmosphere parameters in irrigated and natural ecosystems of semi-arid Brazil. Journal of Hydrology, 362, 110-127 (2008).

[14] Bastiaanssen, W.G.M.; Ali, S. A new crop yield forecasting model based on satellite measurements applied across the Indus Basin, Pakistan. Agriculture, Ecosystems and Environment, 94, 32-340 (2003).

[15] UNESP - Universidade Estadual Paulista. Faculdade de Engenharia de Ilha Solteira. Departamento de Fitossanidade e Engenharia Rural e Solos - DEFERS. Área de Hidráulica e Irrigação. Acesso à base diária: Ilha Solteira (2013). http://clima.feis.unesp.br

[16] Teixeira, A.H.C.; Bassoi, L.H. Crop water productivity in semi-arid regions: from field to large scales. Ann. Arid Zone (48), 1-13 (2009). 